\title{
The implementation of work-based incentive at Law Firm and Secretary Staffs At Universitas Pendidikan Indonesia
}

\author{
Budi Rahadian \\ Prodi Magister Manajemen, Fakultas Pasca Sarjana \\ Universitas Komputer Indonesia \\ Bandung, Indonesia \\ b.rahadian@upi.edu
}

\author{
Deden A. Wahab Sya'roni \\ Prodi Magister Manajemen, Fakultas Pasca Sarjana \\ Universitas Komputer Indonesia \\ Bandung, Indonesia \\ dedenwahab@unikom.ac.id
}

\begin{abstract}
The study attempts to identify the implementation of work-based incentive, called Insentif Berbasis Kinerja (IBK), at Law Firm and Secretary Staffs at Universitas Pendidikan Indonesia. To increase the productivity of an organization, pay-for-performance (PFP) is usually implemented in an institution. IBK is one of the forms of PFP. This paper is a part of a bigger research about the influence of IBK towards the administration staffs work motivation and discipline in Biro Hukum dan Kesekretariatan division at Indonesia University of Education. The study in this paper is a part of the preliminary research which focused on the implementation of IBK system. Qualitative descriptive is employed as the research method of the study. The data collection was conducted through literatures study of the Law Firm and Secretariat documents, observation, and semistructured interview. The result of the study reveals that the implementation of IBK system is conducted through some steps, namely; planning the RKB, the RKB verification, collecting the physical proof, reporting the RKB, the RKB data input, reporting the input data to the directorate of finance, transferring the money based on the data to the staff's bank account. Besides, the study also describes some considerations that were taken into account in the process of the IBK enactment.
\end{abstract}

Keywords-IBK, pay-for-performance (PFP), workbased incentive, motivation, discipline

\section{INTRODUCTION}

Human resource is the most important condition to increase the productivity of an organization needs to protect the assets of employees by making them feel safe and secure in doing their jobs. One of the ways to promote the employees' job satisfaction is by giving them compensation based on their work performance [1] [2] [3].

This paper is a part of a bigger research on the influence of the work-based incentive towards the employees' work motivation and discipline. The research took place at Indonesia University of education, in one of divisions called Biro Hukum dan Kesekretariatan. The research identifies the implementation of the work-based incentive, called insentif Berbasis Kinerja (IBK) towards the administration staffs in the division. This incentive system has been implemented since January 2018. Therefore, in such short period of time, the consequences of implementing the new incentive system have not been discussed yet in any of research paper. The potential effects - the strengths and the drawbacks-from the enactment of IBK towards the employees' work motivation and discipline, particularly at the mentioned division at One of University in have not been investigated. Therefore, this paper attempts to fill the gap of study. Moreover, discussion about compensation is still considered as under-research in the area of Human Resource Management [1], [3]. The procedures of the IBK implementation are also unleashed. The paper also ended by presenting the conclusions of the study and some recommendations for the stakeholders regarding the implementation of the work-based incentive system. The paper attempts to only cover the discussion of the administration staffs' IBK system at Biro Hukum dan Kesekretarian, Indonesia University of Education. Therefore, the discussion about the lecturers' or university staffs' IBK implementation at other divisions is not available.

\section{A. Work-Based Incentive}

Since incentive is one of the forms of compensation [1], thus, the discussion of incentive could not be separated from the discussion compensation. Compensation is a central issue in an organization because it has a strong influence towards the performance of the employees and organization [2], [3]. Moreover, it is believed that compensation could enhance the employees' work performances which in turn increase the productivity of an organization. Therefore, it is the reason why compensation is the most fundamental basic element in the discussion of human resource (HR) [1].

Generally, the framework of compensation is divided into two forms, namely, cash and benefit [4], [5]. Compensation in the cash form is usually known as basepay and work-based incentive, that is also called pay-forperformance (PFP). The other form of compensation is benefit. Benefit is usually given in a form of education and training, conducive work place, motivation reinforcement, and insurance [1], [4]. From the explanation, it can be seen that incentive is one of compensation type in the form of cash. Meanwhile, the difference between base-pay from incentive can be seen from the method of the implementation. Base-pay is determined based on the employees' skills and competencies, negotiated since the first day they were hired in the organization, while incentive 
is really depends on the distributed method work performance measurement approach [1], [6], [7].

Although experts in compensation field agree that incentive is one of the forms of cash compensation, there is other perspective that viewed incentive not only in cash form, but also in nonmonetary form, called 'tangible incentives' [8]. It is said that 'tangible incentive' is more powerful than cash incentive when it is seen from the psychological concept of justifiability, social reinforcement, separability, and evalualibility. In short, reference [8] confirms that noncash incentive is more successful since it has more imaginary visual towards luxurious thing that can be enjoyed without having the need to pay for it [8]. However, the noncash incentive has also drawbacks, that it is not as flexible as cash incentive [8].

There is a complex problem in addressing the topic of compensation, especially when specific topic of PFP is discussed, since compensation has two main scopes, namely macro and micro level [1]. In macro level, compensation has wider traits, since it includes the organizational perspective of determining the structural pay level. Meanwhile, micro level of compensation discuss more specific issues, such as the differences of payment between employees, the measurement of individual work performance, and also PFP [1]. Thus when giving incentive is believed to have a positive correlation, that is to increase the employees' work performance as well as job satisfaction [9], and the absence of it can lead to unloyalty and high rates of turnover and absenteeism [10]. To sum up, in the perspective of macro compensation, incentive does not necessarily and automatically increase the organization's productivity [1].

Incentive is often defined as the direct pay given to the employees related to the work performance and gains sharing with the firm [11]. Furthermore, incentive also means the stimulus for the employees to show higher work performance that the one that has been standardized. Finally, incentive is the final result of the combination of measurement of certain components conducted by the firm [12] by applying a certain approach and method to be given to the employees [6], [7].

In micro level, incentive critically influences the quality and effectiveness of human resources [3]. Therefore incentive could not be separated from the productivity of an organization or firm. In this paper, incentive is discussed in relation with the attempt of enhancing the employees' motivation and discipline. Therefore, the next discussion moves to the motivation and discipline; how the firm enhances them through the incentives. In other words, how the One of University in can enhance the work motivation and discipline of administration staffs at Biro Hukum dan Kesekretariatan through the implementation of IBK.

\section{B. Work Motivation}

The employees' motivation is the central issues for the leader of a firm or organization [13]. The discussion on motivation at the individual level at the work place usually evolves in the three theories of motivation, namely, expectancy theory, equity theory, and agency theory [1]. The expectancy theory highlights the motivation based on work contract: the expectations and sanctions agreed in the beginning of the employment [14], [15]. Meanwhile, in the equity theory, the discussion focuses on how the firm or organization achieve the equality in treating the employees fairly; in other words, how the firm meets the employees needs based on their work performance [15]. Finally, the third theory is agency theory. In this theory, the employees' ownership towards the firm or organization is maximized [16], to enhance the work motivation. In other words, employees have an intrinsic motivation to do all the best as if they were the owner of the firm or organization.

Discussing about the motivation in the workplace, Herzberg's theory of two-factors cannot be separated. It seems that Herzberg's theory lies as a basic foundation in the investigation of motivation, especially when it discuss from the dichotomy of intrinsic and extrinsic [17], [18]. Herzberg's motivation-hygiene theory argues that job satisfaction and job dissatisfaction result from different causes [17]. Furthermore, reference [17] defines motivators as intrinsic to the job as the work itself, and hygiene factors as extrinsic to the job, reflects the context in which the work itself was performed. The aspects intrinsic motivation are promotion, achievement, responsibility and recognition, whereas aspects in extrinsic motivation include working conditions, interpersonal relations, company polities and salary, and supervision [17], [18], [19], [20]. Moreover, other research show that the effect of choice has given the employees the feeling of more motivated [21], [22]. It means that they engage the task performance indirectly through intrinsic motivation [22]. Therefore, by maintaining the extrinsic and intrinsic aspects of motivation, employers gain the benefits of employees' work performances to strengthen firms' productivity.

\section{Work Discipline}

Basically, the term of work discipline has a wide concept. Work discipline is a strength, develops inside the employees so that they conform themselves to the firm's decisions and regulations [23]. The discussion of discipline often intersects with the discussion of motivation, since discipline is one of the forms of intrinsic motivation [22]. In Indonesian context, some research on the influence of motivation and also creativity and innovation towards the employees' work performance as the form of discipline have been conducted (for example research by reference [24] and [25].

There are factors that influence one's discipline, such as employees' goal and ability, the employer's role model and supervision, reward and punishment, equality between employees, and also humanity relationship in the workplace [20]. Furthermore, reference [26] states that there are indicators to measure the employees' discipline, namely attendance punctuality and intensity, effectiveness in handling office's equipment, task completing accuracy based on the applied procedure, and high level of responsibility. Specifically, work discipline often refers to the indicator of attendance punctuality [10]. 


\section{The Incentive System at Indonesia University of Education.}

One of University in is one of the state universities in Indonesia. As the state-owned university, all of the management, namely financial and non-financial, is maintained by the Indonesian government under the ministry of higher education. However, since 2014, although this university is still considered as state-owned one, its status was changed, and considered similar to a private enterprise (or it is called Perguruan Tinggi Negeri-Berbadan Hukum, PTN-BH). As a PTN-BH, One of University in has autonomy to manage its own administration tasks- to select, appoint or discharge employees, and the financial tasks - to determine all the monetary-related policies. Therefore, since then, this university has its own policies regarding the incentive system for its employees.

The work-based incentive given to the university staffs, which consist of the lecturers and administration staffs, is called IBK (Insentif Berbasis Kinerja). In this university context, incentive means additional income that is given based on the individual performance. The calculation and determination between lecturers' and administration staffs' incentives in the IBK were conducted and implemented differently. This paper only focuses on the administration staffs' incentive implementation.

Before the implementation of IBK, UPI applied giving incentives for its staffs under govenment control which was called work-allowances (tunjangan kinerja, or tukin, for short). However, since the status of the university was changed to PTN-BH, the ministry of national education had stopped the allowances.

Therefore, the university should seek another incentive system as a substitute of the tukin. In the middle of 2015, the incentive system called 'remuneration' was enacted. However, in 2016, it was changed into P3 patterns, namely, pay-for-person, pay-for-position, and pay-for-performance. In 2017, the term 'remuneration' was changed into IBK, since the incentive is focused more on the work performance. In 2018, the system of IBK is modified by implementing the point system, where 1 point values $\mathrm{Rp}$ 100.000. [30]. In the implementation of 2018 IBK system, the incentive is given based on three components, namely, position, work performance, and attendance components. The component of position implements the job class and job price, with the attendance as the deduction point. Meanwhile, the component of performance is measured from monthly performance report (it is called Laporan Kinerja Bulanan, LKB) and supporting element. The supporting element consists of, involving as a committee in an event/ ad hoc, regular attendance in a monthly flag ceremony, and overtime working.

\section{RESEARCH METHOD}

The paper is written as a part of a bigger research investigates the influence of work-based incentive (Insentif Berbasis Kinerja, IBK) towards the administration staffs' work motivation and discipline. Qualitative descriptive research design was employed in the study. The data were collected through literatures study of Biro Hukum and
Kesekretariatan documents, observation, and semistructured interview with one of the decision makers of the IBK implementation policy at Indonesia University of Education. The data were then qualitatively analyzed by given coding until the themes and key concepts were identified. The identified concepts of the IBK implementation were then cross-checked with the references to be synthesized with the discussed theories and previous research, to be examined whether or not the result of the study could fill in the gaps of the discussion in the field of compensation in the work-place.

\section{RESULTS AND DISCUSSIONS}

\section{A. The Measurement of IBK}

As it is mentioned previously, the measurement of incentive in IBK consists of three main components, namely position class, work performance, and attendance. The calculation of IBK based on position class component is calculated by $50 \%$ off of job class and job price. The absenteeism is applied as the deduction points of position component. The deduction is applied based on the following cases:

- Not present at the office without former notice: $5 \%$ deduction of incentive from the the position components.

- Not present with former notice/ permission: $3 \%$ deduction of incentive from the the position components.

- More than two-day sick leave with doctor sick letter: $1 \%$ deduction of incentive from the the position components.

- Propose job on-leave on important resason: 2\% deduction of incentive from the the position components.

- Propose job on-leave for maternity purpose: $4 \%$ deduction of incentive from the the position components.

Furthermore, the calculation based on work performance component depends on the job class and job price as the basic foundation. The parameter used in calculating the component is based on the work performance achievement in the current month, which is evaluated in the next month so that the payment of the incentive can be applied in real time. The work performance parameter is divided into two elements, namely LKB and supporting elements in the form of involving as a committee in an event/ ad hoc, regular attendance in a monthly flag ceremony, and overtime working.

Finally, the last component is the staffs' attendance. Generally, all of the staffs have 7,5 hours of workload on every work-day. For every in-time arrival (before 7 o'clock), the staffs receive additional incentive Rp 50.000. While for on-time arrival (07.01 until 08.00), they receive additional incentive $\mathrm{Rp} 35.000$. Whereas for every late arrival (after 8 o'clock), the staffs do not receive any additional incentive. 
From the implementation of IBK in the division at Indonesia University of Education, it can be seen that the institution conduct the calculation of the incentive from the combination of measurement of certain components [12]. Itis also relevant with previous research that IBK is implemented by applying a measurement approach and method [6], [7].

\section{B. The Procedure of the IBK Distribution}

Having determined the measurement of IBK for every staffs based on position class, work performance and attendance, the next is how to distribute the incentive based on the measurement to the staffs. the Finally, the last component is the staffs' attendance. There are 10 stages in the procedure of the IBK distribution to the staffs.

The first stage, the empoyees are asked to make a planning of their work performance for a month in advance in the form of Rencana Kinerja Bulanan (RKB). The RKB sheet explains the activities that are planned to be conducted in the month ahead. Secondly, after filling in the RKB sheets, the staffs then report the RKB to the head of division for the verification. Thirdly, at the end of the month, the staffs collects the physical proofs whether or not the planned activities are applied. The physical proofs collection is reported in the sheet of Laporan Kinerja Bulanan (LKB). The fourth stage of the procedure is the LKB data input by the LKB operator into the LKB system. Then at the fifth stage, LKB operator reports the data to the IBK operator.

The sixth stage, the IBK operator input the data from the LKB operator to the application. In the seventh stage, the data in the IBK application are sent to the human resource (HR) division and the directorate of finance. At the eightth stage, the procedure of the IBK calculation diverges into two divisions; the HR division and the directorate finance division. The HR division calculates the IBK points based on the staffs' attendance, while the directorate of finance calculates the points of the staffs' work performance based on the LKB data from the LKB operator. At the ninth stage, the overall points of attendance and work performance are then calculated to determine the incentive received. Finally, the last stage, the directorate of finance transfers some amount of money to the staffs' bank account.

From the study, it is revealed that the procedure of IBK implementation has a lengthy process. The stages in the procedure are implemented to assure the reability of the approach and method in the incentive measurement. The rationale behind the long process of the procedure is conducted to make sure that every staffs deserve the incentive based on the work they have accomplished, since characteristic of IBK is compensation based on PFP.

\section{IBK in the context of Enhancing the Staffs' Motivation and Work Discipline}

The final goal of incentives for any firm is to increase the firm's productivity [2], [3], although it is not always applied since compensation has macro and micro scopes [1]. Therefore, giving incentive can be succeeded in enhancing the employees' motivation and work discipline, but it is not automatically enhancing the institution's productivity [1],
[7]. Since the study is more focused to the individual traits of staffs' motivation and work discipline, the effects of incentive towards the university's productivity and performance is not be discussed.

The monetary incentive applied in IBK aims to encourage the staffs' motivation and work discipline. By having additional income from the IBK, the needs of the staffs could be fulfilled that can lead to the job security and satisfaction [2] [5] [9]. The implementation of IBK functions as the extrinsic motivator to stimulate the better work performance from the staffs. Therefore, IBK is considered as the hygiene factor, when it is perceived from the Herzberg's theory of motivation [17], [18], [19].

Consequently, the IBK system could be considered as successful in enhancing the staffs' extrinsic motivation. However, it is not necessarily enhancing the staffs' intrinsic motivation [13]. Meanwhile, staffs' intrinsic motivation is believed more powerful for the organization's productivity since it derives from inside personal of the individual as it is manifested in the form of self-determination and autonomous motivation [27], [28].

Based on the data from the interview with one of the decision maker of the IBK implementation in the university, one of the strength of IBK is considered as an effective way of giving incentive since it really measure the staffs' work performance. He added that IBK is considered an efficient way in giving the incentive since the amount is still far below the national incentive standard. Despite the strengths, the drawbacks of the IBK system can be identified. Based on the information from one of the IBK team, the drawbacks are mostly caused by the incomprehension of the staffs towards the system.

\section{CONCLUSIONS AND RECOMENDATIONS}

From the study, it can be concluded that the implementation of IBK is divided into two main discussions, first the measurement of the amount, and second, the procedures of the distribution. The measurement of IBK is conducted based on three components, namely, the position class, the work performance, and the last is the attendance. While the procedures of the IBK distribution is applied through 10 stages. The implementation of IBK is believed to enhance the staffs' motivation and work discipline. However the incentive is tend to develop the extrinsic motivation. The IBK have potential detrimental effects on the staffs' self-determination and autonomous motivation, since they work more for the sake of the compensation.

More following research should be conducted to identify the effects of the IBK towards the staffs' long-term motivation, both intrinsically and extrinsically. When IBK could facilitate the development of the staffs' extrinsic motivation, the stakeholders should also consider the sustainability of the staffs' intrinsic motivation to assure the university's better performance and productivity. 


\section{REFERENCES}

[1] S. A. Conroy, Y. J. Yoon, P. A. Bamberger, B. Gerhart, N. Gupta, A J. Nyberg, S. Park, T-Y. Park, J. D. Shaw, and M. C. Sturman, "Past, present and future compensation research perspectives," in Compensation \& Benefits Review, vol. 47, no. 5-6, pp.207-215, 2015.

[2] B. Gerhart, and S. Rynes. "Compensation: Theory, evidence, and strategic implications," Thousand Oaks, CA: Sage, 2003.

[3] N. Gupta, and J. D. Shaw. "Employee compensation: The neglegted area of HRM research," in Human Resource Management Review vol. 24, pp. 1-4, 2014

[4] G. Milkovich, J. Newman, and B. Gerhart. "Compensation (11th ed.)," New York, NY: McGraw-Hill, 2013.

[5] D. L. Morrell. "Employee perceptions and the motivation of nonmonetary incentives," in Compensation \& Benefits Review, vol. 43, no. 5, pp. 318-323, 2011.

[6] S. A. Conroy, and N. Gupta. "Team pay-for-performance: The devil is in the details," in Group \& Organization Management, vol. 4, no. 1, pp. 32-65, 2016.

[7] S. Park, and M. C. Sturman. "Evaluating form and functionality of pay-for-performance's plans: The relatives incentives and sorting effects of merit pay, bonuses, and long-term incentives," in Human Resources Management, vol. 55, pp. 697-719, 2016.

[8] S. A. Jeffrey, and V. Shaffer. "The motivational properties of tangible incentives," in Compensation \& Benefits Review, pp. 44-50, 2007.

[9] G. D. Jenkins, Jr., A. Mitra, N. Gupta, and J. D. Shaw. "Are financial incentives related to performance? A meta-analytic review of empirical research," in Journal of Applied Psychology, vol. 83, pp. 777-787, 1998.

[10] M. L. Williams, M. A. McDaniel, and N. T. Nguyen. "A metaanalysis of the antecedents and consequences of pay level satisfaction," in Journal of Applied Psychology, vol. 91, pp. 392-413, 2006

[11] U, Ude. \& Coker, M. A. 2012. "Incentive schemes, employee motivation and productivity in organizations in Nigeria: analytical linkages," IOSR Journal of Business and Management, Vol. 1, Issue 4, pp. 32-39.

[12] H. D. Sejati, A. Komariah, and Abubakar. "Pengaruh insentif terhadap disiplin kerja pegawai negeri sipil di PPPPTK TK dan PLB Bandung," in Jurnal Adpend, pp. 91-101, 2015.

[13] V.C. Ganta. "Motivation in a workplace to improve the employee performance," in International Journal of Engineering Technology, Management and Applied Sciences, vol. 2, no. 6, pp. 221-230, 2014.

[14] K. T. Lambright. " An update of a classic: Appliying expectancy theory to understand contracted provuder motivation," in Administration \& Society, vol. 42, no. 4, pp. 375-403, 2010.

[15] S. Hayibor. "Equity and expectancy considerations in stake holder action," in Business \& Society, vol. 51, no. 2, pp. 220-262, 2012.

[16] B. Panda and N. M. Leepsa. "Agency theory: Review of theory and evidence on problems and perspectives," in Indian Journal of Corporate Governance, vol. 10, no. 1, pp. 74-95, 2017.

[17] F. Herzberg. "One more time: How do you motivate employees?," in Harvard Business Review, Reprint No. 87507, September-October 1987.

[18] I. I. Udechukwu. "Correctional officer turnover: Of Maslow's Needs Hierarchy and Herzberg's Motivation Theory," in Public Personnel Management, vol. 38, no. 2, 2009.

[19] D. A. Sachau. "Resurrecting the motivation-hygiene theory: Herzberg and the positive psychology movement," in Human Resource Development Review, vol. 6, No. 4, pp. 377-393,2007.

[20] M. S. P. Hasibuan. "Manajemen sumber daya manusia, edisi ke 19," Jakarta: Bumi Aksara, 2016

[21] E. A. Patall, H. Cooper, and J. C. Robinson. "The effects of choice on intrinsic motivation and related outcomes: A Meta-analysis of research findings," in Psychological Bulletin, vol. 134, no. 2, pp. 270300, April 2008.
[22] E. A. Patall, B. J. Sylvester, and C. Han. "The role of competence in the effects of choice on motivation," in Jounal of Experimental Social Psychology, vol. 50, pp. 27-44, 2014.

[23] W. J. Sumaki, R. N. Taroreh, and D. Soepeno. "Pengaruh disiplin kerja, budaya organisasi, dam komunikasi terhadap kinerja karyawn PT. PLN (PERSERO) wilayah Sulutenggo area Manado," in Jurnal Berkala Ilmiah Efisiensi,vol. 15, no. 5, pp. 538-549, 2015.

[24] A. Febriansyah, and D. A. W. Sya'roni. "Analisis pengaruh kemampuan dan motivasi kerja terhadap kinerja pegawai pada PT> Lakumas Rancaekek Bandung," in Jurnal Ilmiah Magister Managemen UNIKOM, vol. 1, no. 1, pp. 25-43, 2015.

[25] R. Riansyah, and D. A. W. Sya'roni. "Faktor-faktor yang mempengaruhi kreatifitas dan inovasi serta implikasinya terhadap kinerja karyawan pada konsultan perencanaan dan pengawasan arsitektur di kota Serang provinsi Banten," in Jurnal Ilmiah Magister Managemen UNIKOM, vol. 2, no. 1, pp. 1-17, 2017.

[26] Robbins, S.P.\& Judge, T. A. 2013. Organizational Behavior, 15 Edition, Pearson.

[27] M. Gagné, and J. Forest. "The study of compensation systems through the lens of self-determination theory: Reconciling 35 years of debate," in Candian Psychology, vol. 49, no. 3, pp. 225-232, 2008.

[28] M. Gagné, and E. L. Deci. "Self-determination theory and work motivation," in Journal of Organizational Behavior, vol. 26, pp. 331362, 2005. 